\title{
Author Correction: Attraction Pheromone of The Benthic Diatom Seminavis robusta: Studies on Structure-Activity Relationships
}

\author{
Christine Lembke $^{1} \cdot$ Daniel Stettin $^{1} \cdot$ Franziska Speck ${ }^{1} \cdot$ Nico Ueberschaar $^{1} \cdot$ Sam De Decker $^{2} \cdot$ Wim Vyverman $^{2}$. \\ Georg Pohnert ${ }^{1,3}$
}

Published online: 2 March 2019

(C) Springer Science+Business Media, LLC, part of Springer Nature 2019

\section{Author Correction: Journal of Chemical Ecology (2018) 44:354-363 \\ https://doi.org/10.1007/s10886-018-0944-2}

The original version of this article unfortunately contained a mistake. The chemical structure of compound $\mathbf{6}$ in Fig. 1 was incorrect. The tested compound $\mathbf{6}$ in this study was $(3 S, 8 \mathrm{a} S)$ 3 -isobutylhexahydropyrrolo[1,2-a]pyrazine-1,4-dione as shown in the corrected version of Fig. 1 here.

The author apologizes for this oversight and for any confusion it may have caused.

The online version of the original article can be found at https://oi.org/ 10.1007/s10886-018-0944-2

Georg Pohnert

Georg.Pohnert@uni-jena.de

1 Institute for Inorganic and Analytical Chemistry, Bioorganic Analytics, Friedrich-Schiller-Universität Jena, Lessingstrasse 8, D-07743 Jena, Germany

2 Laboratory of Protistology and Aquatic Ecology, Department of Biology, University Gent, Krijgslaan 281 S8, 9000 Gent, Belgium

3 Max Planck Institute for Chemical Ecology, Hans-Knöll-Str. 8, D-07745 Jena, Germany 
Fig. 1 Compounds tested in this study. The natural pheromone $(S, S)$-1 (gray box) was synthesized stereospecifically, as well as with undefined

stereochemical composition (1). Stereoisomers of 1 and 2 were separated by chiral HPLC

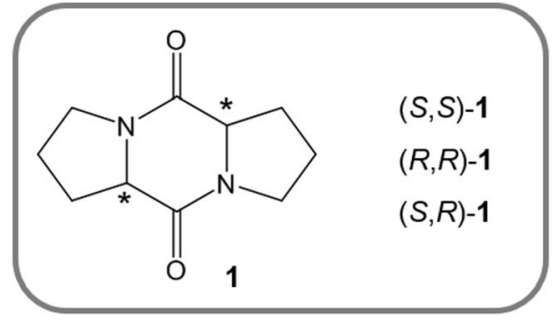<smiles>O=C1[C@H]2CCCCN2C(=O)[C@H]2CCCCN12</smiles>

$(R, R)-2$<smiles>O=C1CCCCC1N1C[C@@H](O)CN1C(=O)[C@H]1C[C@@H](O)CN1</smiles><smiles>CCC[C@@H]1NC(=O)[C@H](CCCCCN2CC(=O)N(CCC)CC2=O)NC1=O</smiles><smiles>CC(C)C[C@@H]1NC(=O)[C@@H]2CCCN2C1=O</smiles><smiles>C[C@@H]1NC(=O)[C@@H](C)NC1=O</smiles><smiles>O=C1NCC(=O)N2CCC[C@H]12</smiles> 